\title{
Tumorous conditions of the pediatric hand and wrist: Ten-year experience of a single center
}

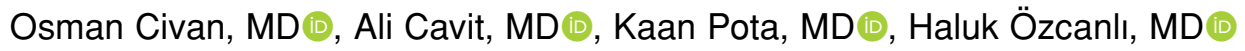 \\ Department of Orthopedics, Akdeniz University Faculty of Medicine Antalya, Turkey
}

Hand tumors are uncommon and the malignant ones are less commonly seen pathologies. ${ }^{[1]}$ Pediatric hand tumors are particularly rare and one of the less investigated topics of musculoskeletal tumors.

Some tumors and tumor-like lesions are common in a different part of the body while some are common in the hand. Hand tumors and tumor-like lesions mostly have a different distribution from the whole body and ganglion cysts are the most common tumor-like lesions of the hand..$^{[2,3]}$

The pediatric population or families mostly concern about the growing mass of the hand and this is the most common complaint for applying to the hospital. General examination of the pediatric population is mostly challenging, sensitive and different from the adults. Also, the distribution of the ganglion cyst on the hand may differ from the adults. ${ }^{[4,5]}$

Pediatric hands may also have both benign and malignant tumor conditions. However, malignant tumors are rarely seen. ${ }^{[6]}$ Having the knowledge of the distribution of the tumors on each part of the body and also of the hand of the pediatric population makes the evaluation and the diagnosis of the children with a

Received: March 19, 2020

Accepted: April 15, 2020

Published online: June 18, 2020

Correspondence: Osman Civan, MD. Akdeniz Üniversitesi

Tıp Fakültesi Ortopedi ve Travmatoloji Kliniği, 07070 Kampüs,

Antalya, Türkiye.

E-mail: civanosman@gmail.com

Doi: $10.5606 /$ ehc. 2020.74972

Citation: Civan O, Cavit A, Pota K, Özcanlı H. Tumorous conditions of the pediatric hand and wrist: Ten-year experience of a single center. Jt Dis Relat Surg 2020:31(2):341-345.

\section{ABSTRACT}

Objectives: This study aims to evaluate the distribution and prevalence of pediatric hand tumors and tumor-like lesions according to age and gender.

Patients and methods: We retrospectively examined the details of hospital records of 646 patients who were operated for hand mass between January 2009 and January 2019 and whose pathological diagnosis was established in the same hospital. A total of 54 patients (18 males, 36 females; mean age 12.07 years; range, 3 month to 17 years) under 18 years of age who had been operated for the wrist or hand mass were included in the study.

Results: Out of 54 tumors, 53 were benign (98\%) and one was malignant $(2 \%)$. There were 42 soft tissue tumors $(78 \%)$ and 12 bone tumors (22\%). The most common soft tissue mass was ganglion cyst $(n=12)$. Six out of 12 ganglion cysts were on the dorsal side of hand or wrist and six were on the volar side. The distribution of the tumors according to gender was not statistically significant $(\mathrm{p}=0.73)$. We had two recurrences: one patient with giant cell tumor of the tendon sheath and one with palmar fibromatosis.

Conclusion: Pediatric hand/wrist masses are mostly benign tumorous conditions. The location of the pathologies may be different from the adults. Diagnosis of the tumor should be established carefully clinically and radiologically while malignant tumors should be kept in mind by both pediatricians and orthopedic surgeons.

Keywords: Hand, hand tumors, ganglion cyst, pediatric hand, pediatric tumors.

hand mass easier. In this study, we aimed to evaluate the distribution and prevalence of pediatric hand tumors and tumor-like lesions according to age and gender.

\section{PATIENTS AND METHODS}

In this study, we retrospectively examined the details of hospital records of 646 patients who were operated for hand mass in Akdeniz University Faculty of Medicine, Department of Orthopedics 
between January 2009 and January 2019 and had the pathological diagnosis in the same hospital. A total of 54 patients (18 males, 36 females; mean age 12.07 years; range, 3 month to 17 years) under 18 years of age at the operation time and who could be followedup for a minimum of one year were included in the study.

The hospital's archiving system (Mia-Med version 1.0.1.2808, Mia Technology, Ankara, Turkey) was used to obtain the demographic information, pathology reports, details of surgery, pre- and intraoperative diagnosis, and follow-up examination reports. The study protocol was approved by the Akdeniz University, Faculty of Medicine Ethics Committee (Date: 04 May 2015, Decision Number: 239). The study was conducted in accordance with the principles of the Declaration of Helsinki.

\section{Statistical analysis}

We applied descriptive statistical analysis and Fisher's exact test to compare the distribution of the tumor. All statistical analyses were conducted using
PASW Statistics version 19.0 software (SPSS Inc., Chicago, IL, USA) and $p$ value $<0.05$ was considered as statistically significant.

\section{RESULTS}

All patients had been operated for the wrist or hand mass and had a pathological diagnosis after an excisional biopsy. Demographic data of patients for each pathological diagnosis are presented in Table I. Out of 54 tumors, 53 were benign (98\%) and one was malignant (2\%, synovial sarcoma). There were 42 soft tissue tumors (78\%) and 12 bone tumors (22\%).

The most common soft tissue mass was ganglion cyst ( $n=12,6$ males and 6 females). Six out of 12 were on the dorsal side of the hand or wrist and six were on the volar side. The second common reason for the hand mass was the giant cell tumor of the tendon sheath (GCTTS) $(n=9)$. In eight out of nine patients with GCTTS, the tumor was on the volar side and only in one patient the GCTTS was on the dorsal side (Figure 1). If we accept the ganglion cyst as a tumorlike lesion, GCTTS was the most common soft tissue

TABLE I

Demographic data of patients for each pathological diagnosis

\begin{tabular}{|c|c|c|c|c|c|c|}
\hline \multirow[b]{2}{*}{ Pathological diagnosis } & \multirow[b]{2}{*}{ Type of tumors } & \multicolumn{2}{|c|}{ Age } & \multirow{2}{*}{$\begin{array}{c}\text { Gender } \\
\text { Males/Females }\end{array}$} & \multirow[b]{2}{*}{$\mathrm{n}$} & \multirow[b]{2}{*}{$\%$} \\
\hline & & Mean (years) & Range (years) & & & \\
\hline Ganglion cyst & \multirow{15}{*}{ 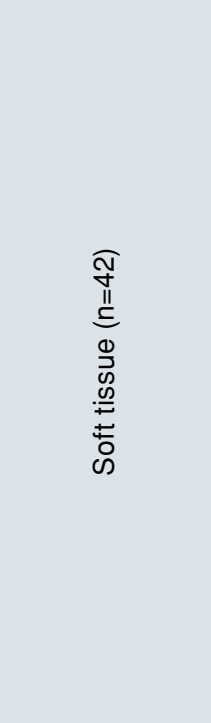 } & 12 & $3-17$ & $6 / 6$ & 12 & 22 \\
\hline Giant cell tumor of tendon sheath & & 13.5 & $10-17$ & $3 / 6$ & 9 & 17 \\
\hline Hemangioma & & 12.5 & $8-17$ & $2 / 4$ & 6 & 11 \\
\hline Fibroma & & 14.3 & $13-16$ & $1 / 2$ & 3 & 6 \\
\hline Traumatic neuroma & & 11.5 & $7-16$ & $0 / 2$ & 2 & 4 \\
\hline Palmar fibromatosis & & 9 & 9 & Male & 1 & - \\
\hline Lipoblastoma & & 0.25 (3 months) & 0.25 (3 months) & Female & 1 & - \\
\hline Papillary endothelial hyperplasia & & 15 & 15 & Female & 1 & - \\
\hline Cutaneous leiomyoma & & 4 & 4 & Female & 1 & - \\
\hline Epidermoid cyst & & 13 & 13 & Male & 1 & - \\
\hline Inclusion body fibromatosis & & 3 & 3 & Female & 1 & - \\
\hline Angiomatosis & & 12 & 12 & Female & 1 & - \\
\hline Junctional nevus & & 4 & 4 & Female & 1 & - \\
\hline Hamartoma & & 16 & 16 & Male & 1 & - \\
\hline *Synovial sarcoma & & 14 & 14 & Female & 1 & - \\
\hline Enchondroma & \multirow{5}{*}{ 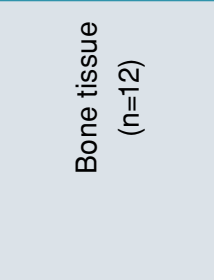 } & 12.1 & $6-17$ & $2 / 6$ & 8 & 15 \\
\hline Osteochondroma & & 14.5 & $12-17$ & $0 / 2$ & 2 & 4 \\
\hline Giant cell reparative granuloma & & 17 & 17 & Female & 1 & - \\
\hline Aneurysmal bone cyst & & 11 & 11 & Male & 1 & - \\
\hline Total & & $\begin{array}{l}12.07 \\
\text { years }\end{array}$ & $\begin{array}{l}3 \text { months- } \\
17 \text { years }\end{array}$ & $\begin{array}{l}18 \text { male, } \\
36 \text { female }\end{array}$ & 54 & 100 \\
\hline
\end{tabular}



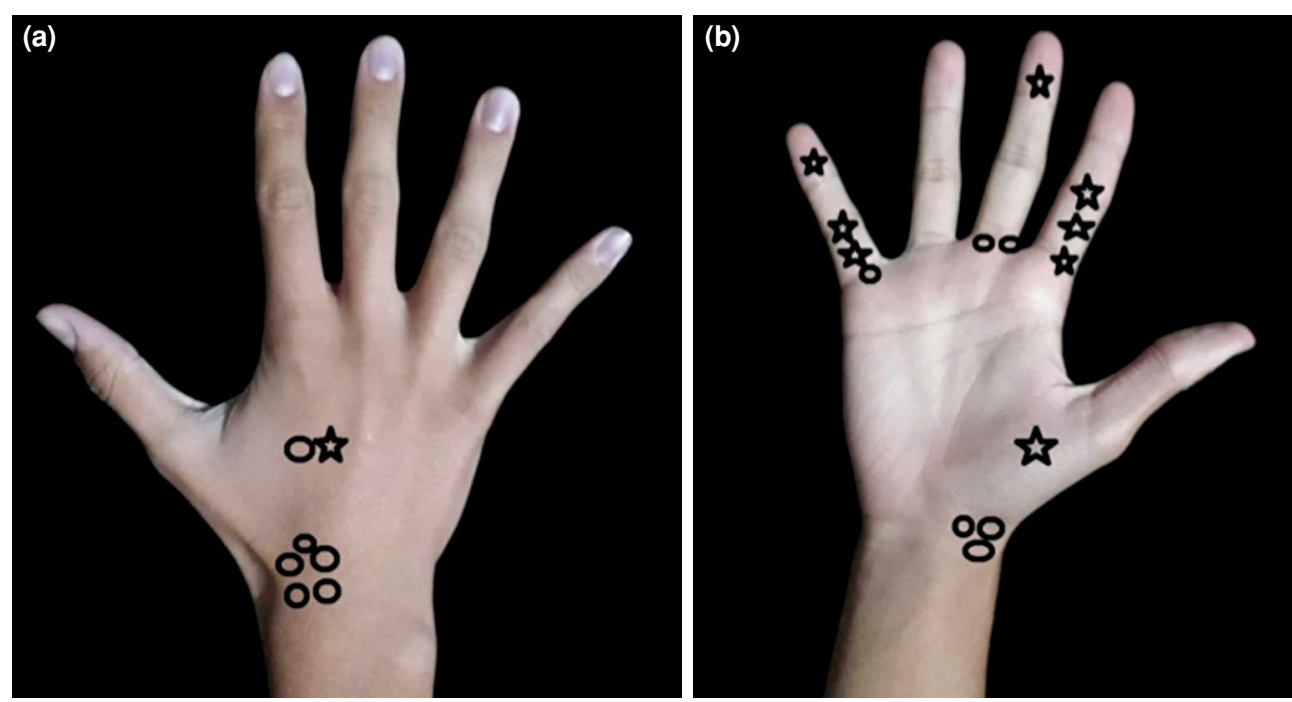

FIGURE 1. Distribution of the most common soft tissue tumorous conditions of hand on a 14-year-old male patient. (a) Dorsal side. (b) Volar side. Elliptical-shaped line shows ganglion cyst and star-shaped line shows giant cell tumor of tendon sheath.

tumor in our study. The third common reason for the hand mass was the enchondroma $(\mathrm{n}=8)$. Enchondroma was the most commonly diagnosed bone tumor in our case series.

Intraoperative photos of two cases are shown in Figures 2 and 3. We had recurrence in two cases: one recurrence in a patient with palmar fibromatosis and one GCCTS.

A comparison of the distribution of the tumors according to gender revealed no statistically significant result $(\mathrm{p}=0.73)$ (Table II).

\section{DISCUSSION}

As seen in our study, tumor and tumor-like lesions of the hands are mostly benign pathologies. Similar results were reported for the adults in some studies. ${ }^{[7,8]}$ There are some different findings from the literature in the current study. One interesting result was the non-dominance of the gender for the ganglion cyst. The prevalence of the ganglion cyst was reported higher in the female gender. ${ }^{[3,4]}$ However, the rate was found to be equal for each gender (50\%-50\%) in our study. To our knowledge, there is no study
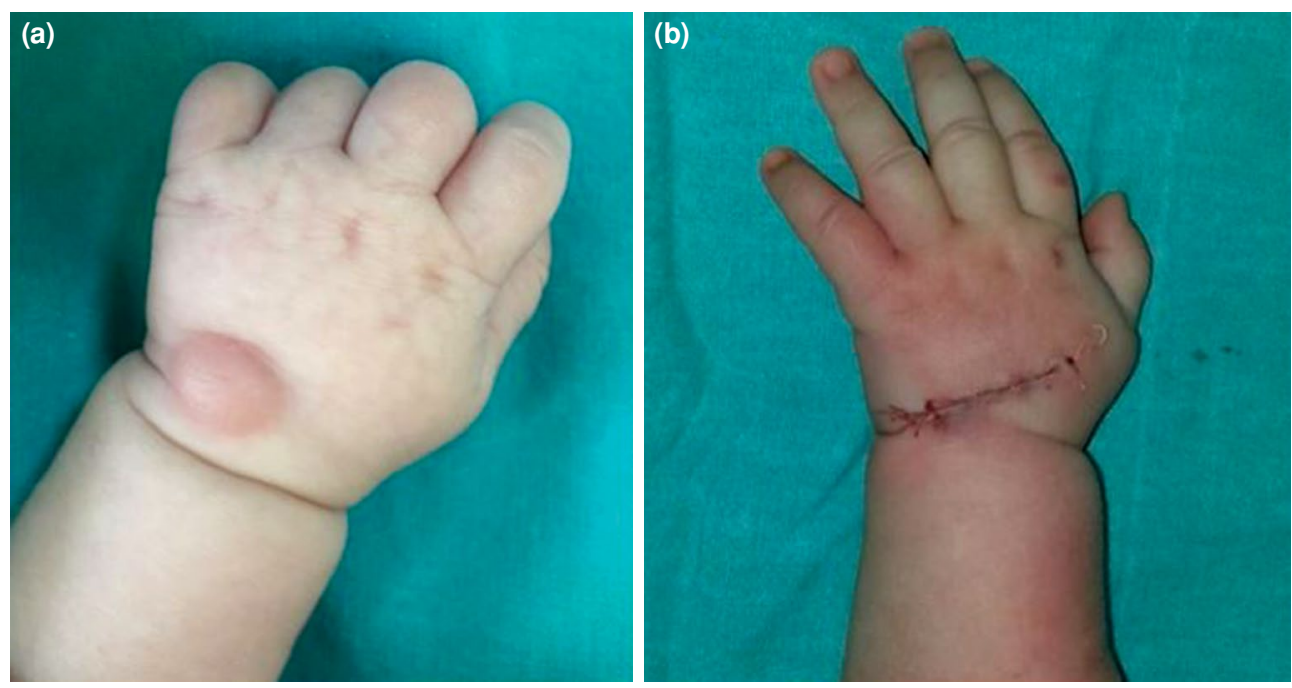

FIGURE 2. Lipoblastoma of hand of a three-month-old female child. (a) Preoperative photo of dorsal hand mass. (b) Postoperative photo of hand. 

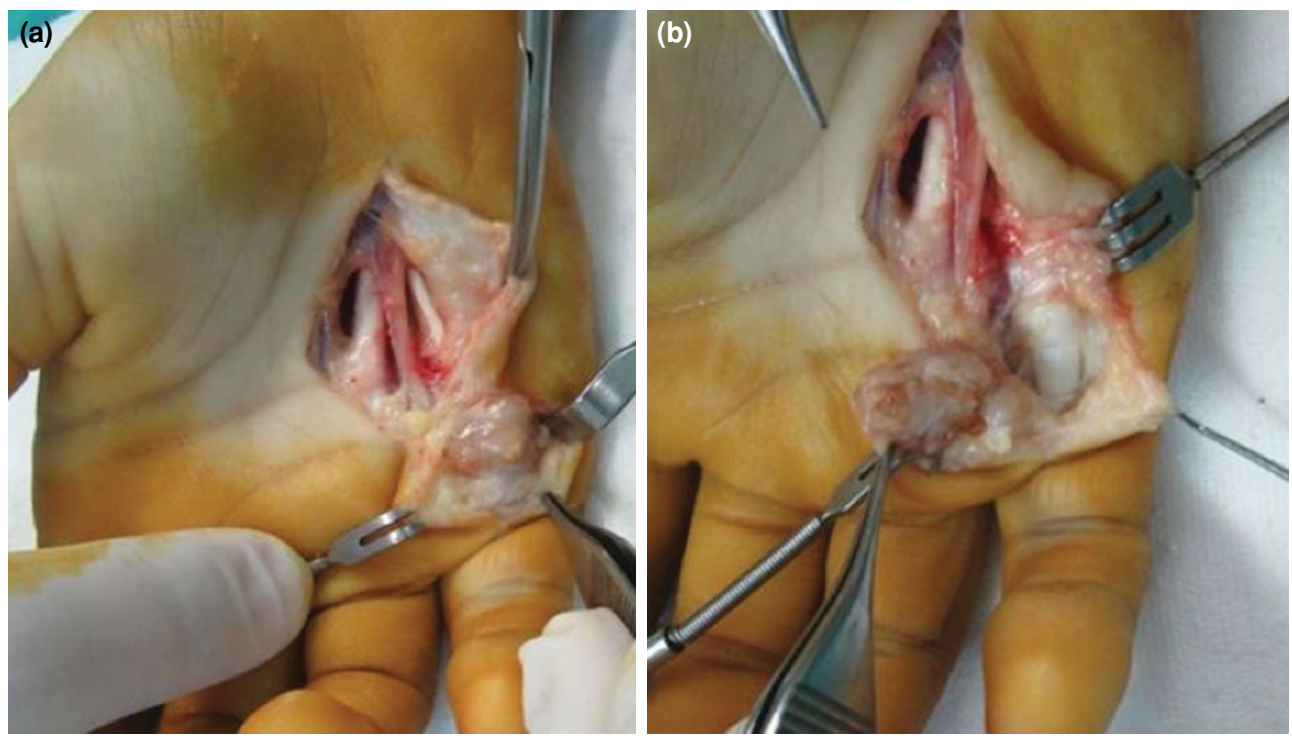

FIGURE 3. Giant cell tumor of tendon sheath (GCTTS) of a 12-year-old male patient. (a) Intraoperative exploration photo of GCTTS. (b) GCTTS is seen on tip of forceps.

reporting the Turkish pediatric population's hand tumor distribution to compare our results. We think one reason for this finding was the ethnic and traditional differences of the Turkish population. Moreover, we are aware that determining the real incidence of ganglion cysts is difficult because of the low rate of need for consulting a doctor. This type of cysts is usually asymptomatic and does not cause functional problems. ${ }^{[4]}$

The location of the ganglion cysts is changeable for different ages. ${ }^{[9]}$ The pediatric population mostly refers to a doctor by a mass on the volar side of the hand or wrist, while the mass is seen on the dorsal side of the hand or wrist in the adult population. ${ }^{[2,5]}$ In our study, we recorded six volar and six dorsal ganglion cysts. The average age of the patients with a volar side ganglion cyst was 9.6 years and the average age of those with a dorsal side ganglion cyst was 14.3 years. These results were similar to the literature. ${ }^{[9]}$

\section{TABLE II}

Distribution of tumor types according to gender

\begin{tabular}{|cccc|}
\hline & Soft tissue & Bone & Total \\
\hline Gender & & & \\
Female & 27 & 9 & 36 \\
Male & 15 & 3 & 18 \\
Total & 42 & 12 & 54 \\
\hline
\end{tabular}

Giant cell tumor of the tendon sheath is the second common reason for the hand and wrist mass in the pediatric population. This is the most common tumor that we recorded in our study. Although GCTTS is commonly seen in adults, it is also the second most common soft tissue tumor-like lesion in pediatric hand according to our study. ${ }^{[3,10,11]}$ The recurrence rate for the GCTTS is $1 / 9(11 \%)$ in our series. This rate is similar to the literature. ${ }^{[12,13]}$ We had recurrence in a 13-year-old female patient. The GCTTS was multilobulated and multifocal in that patient and we think that the reason for recurrence was the inadequate resection. Another recurrence was observed in a nine-year-old male patient with palmar fibromatosis. The rate of recurrence was $100 \%$ for palmar fibromatosis in the present study; however, we believe that it would not be suitable to compare this rate with the literature since palmar fibromatosis of the pediatric hand is reported as case reports in the literature. ${ }^{[14]}$

Enchondromas are one of the benign cartilaginous tumors that have malign transformation potential. ${ }^{[15,16]}$ In our case series, we had eight patients with enchondroma. Curettage and bone grafting were performed for all patients with enchondroma. None of them had malignant transformation to chondrosarcoma and none of them had any recurrence while care should be taken in the follow-up period.

Epidermoid cyst is one of the most common tumor conditions of the hand and wrist. It is mostly 
detected at the age of 30-40 years. Interestingly, we have observed an epidermoid cyst in only one patient. ${ }^{[3,17,18]}$ Lipoma is another common soft tissue tumor of the hand. We recorded no lipoma case. We only included patients with a pathological diagnosis established by excisional biopsy. Lipoma and epidermoid cyst are benign tumors and may result in no complaint. The low rate of these pathological diagnoses would be related to patient preference about the surgical excision. ${ }^{[18]}$

Hemangiomas and glomus tumors are painful tumors of the hand. We had no glomus tumor in our case series while we had six hemangiomas. Hemangiomas grow after birth and mostly cause symptoms in childhood. ${ }^{[18]}$ Surgical excision was performed for the hemangiomas in our series.

Sarcomas are rare malignant tumors of the hand and forearm. ${ }^{[18]}$ In our study, $98 \%$ of the hand or wrist masses were pathologically diagnosed as benign tumors. Only synovial sarcoma was recorded in a 14-year-old female patient as the malignant tumor. We applied a wide margin excision for the tumor. She received adjuvant chemotherapy and radiation. The metastatic tumors of the hand are also rare but case reports were listed in the literature. ${ }^{[19]}$ We had no metastatic case.

In Turkey, families usually take their children to pediatricians even they have a mass in their hand or wrist. This situation makes the pediatric specialist more responsible for the procedure. He or she has to know and inform the family about the type of the hand/wrist mass and tell the family in which situation they should go to an orthopedic surgeon.

This is a single center and retrospectively performed study. Prospectively designed multicenter studies needed for detailed results.

In conclusion, pediatric hand/wrist masses are mostly benign tumorous conditions. The location of the pathologies may be different from the adults. Diagnosis of the tumor should be established carefully clinically and radiologically and malignant tumors should be kept in mind by both pediatricians and orthopedic surgeons.

\section{Declaration of conflicting interests}

The authors declared no conflicts of interest with respect to the authorship and/or publication of this article.

\section{Funding}

The authors received no financial support for the research and/or authorship of this article.

\section{REFERENCES}

1. Sağlık Y, Atalar H, Armangil M, Başarır K, Yıldız Y, Bilgin S. Management of tumors and tumor-like lesions of the hand: a review of 191 patients. Eklem Hastalik Cerrahisi 2013;24:149-55.

2. Nelson CL, Sawmiller S, Phalen GS. Ganglions of the wrist and hand. J Bone Joint Surg [Am] 1972;54:1459-64.

3. Cavit A, Özcanli H, Sançmiş M, Ocak GA, Gürer Eİ. Tumorous Conditions of the Hand: A Retrospective Review of 402 Cases. Turk Patoloji Derg 2018;34:66-72.

4. Simon Cypel TK, Mrad A, Somers G, Zuker RM. Ganglion cyst in children: Reviewing treatment and recurrence rates. Can J Plast Surg 2011;19:53-5.

5. Satku K, Ganesh B. Ganglia in children. J Pediatr Orthop 1985;5:13-5.

6. Colon F, Upton J. Pediatric hand tumors. A review of 349 cases. Hand Clin 1995;11:223-43.

7. Campanacci M, editor. Bone and soft tissue tumors. New York: Springer-Verlag; 1999.

8. Unni KK, editor. Dahlin's bone tumors. General aspects and data on 11,087 cases. 5th ed. Philadelphia: LippincottRaven; 1996.

9. Coffey MJ, Rahman MF, Thirkannad SM. Pediatric ganglion cysts of the hand and wrist: an epidemiologic analysis. Hand 2008;3:359-62.

10. Chung EB, Enzinger FM. Fibroma of tendon sheath. Cancer 1979;44:1945-54.

11. Arıcan M, Turhan Y, Gamsızkan M. A rare localized giant cell tumor of the tendon sheath originating from the ligamentum mucosum: A case report. Jt Dis Relat Surg 2020;31:149-53.

12. Koutserimpas C, Kastanis G, Ioannidis A, Filippou D, Balalis K. Giant cell tumors of the tendon sheath of the hand: an 11-year retrospective study. J BUON 2018;23:1546-51.

13. Ozben H, Coskun T. Giant cell tumor of tendon sheath in the hand: analysis of risk factors for recurrence in 50 cases. BMC Musculoskelet Disord 2019;20:457.

14. Izadpanah A, Viezel-Mathieu A, Izadpanah A, Luc M. Dupuytren contracture in the pediatric population: a systematic review. Eur J Pediatr Surg 2015;25:151-4.

15. Nelson DL, Abdul-Karim FW, Carter JR, Makley JT. Chondrosarcoma of small bones of the hand arising from enchondroma. J Hand Surg Am 1990;15:655-9.

16. Ozcanli H, Alimoglu E, Aydin AT. Malignant transformation of an enchondroma of the hand: a case report. Hand Surg 2011;16:201-3.

17. Beytemür O, Yüksel S. Epidermoid cysts localized on extremities. Eklem Hastalik Cerrahisi 2018;29:27-33.

18. Cooper C, editor. Fundamentals of Hand Therapy: Clinical Reasoning and Treatment Guidelines for Common Diagnoses of the Upper Extremity. Philadelphia: Mosby; 2007.

19. Ozcanli H, Ozdemir H, Ozenci AM, Söyüncü Y, Aydin AT. Metastatic tumors of the hand in three cases. Acta Orthop Traumatol Turc 2005;39:445-8. 